\title{
The Presence of a Natriuretic Factor in Urine of Patients with Chronic Uremia
}

\author{
THE ABSENCE OF THE FACTOR IN NEPHROTIC \\ UREMIC PATIENTS
}

\author{
Jacques J. Bourgoignie, Kuo Hwa Hwang, Ebrahim Ipakchi, and \\ NeAl S. Bricker \\ From the Division of Nephrology, Department of Medicine, Albert Einstein \\ College of Medicine, Bronx, New York 10461
}

\begin{abstract}
A в S T RAC T A gel filtration fraction of serum from chronically uremic patients has been shown previously to produce natriuresis in the rat. In the present studies, the same fraction from urine of uremic patients and normal subjects was studied for its natriuretic activity. Urine samples were obtained from 17 chronically uremic patients (mean glomerular filtration rate [GFR], $8.7 \mathrm{ml} / \mathrm{min}$; mean fractional sodium excretion [FE $\mathrm{Na}_{\mathrm{a}}$, $5.7 \%$ ), and 14 normal subjects. The fraction from the uremic patients produced a significant increase in absolute sodium excretion $\left(\mathrm{U}_{\mathrm{Na}} \mathrm{V}\right.$ ) and $\mathrm{FE}_{\mathrm{Na}}$; the fraction from normal subjects had no statistically significant effect on either $U_{\mathrm{Na}} \mathrm{V}$ or $\mathrm{FE}_{\mathrm{Na}}$; and the difference between the response to the uremic vs. normal fractions was highly significant for both parameters of sodium excretion. When a more concentrated urine fraction from uremic patients was administered, a striking natriuresis was observed with values for $\mathrm{FE}_{\mathrm{Na}}$ rising to levels as high as $12 \%$. Studies also were performed on eight patients with far advanced chronic renal insufficiency and the nephrotic syndrome. The serum fraction was studied in each of these patients and the urine fraction in three. For the group, $\mathrm{U}_{\mathrm{Na}} \mathrm{V}$ in the assay rats decreased by 0.87 $\mu \mathrm{eq} / \mathrm{min}$ and $\mathrm{FE}_{\mathrm{Na}}$ decreased by $1.35 \%$ after infusion of the serum fraction. These results differ significantly from those of patients with chronic uremia without the nephrotic syndrome. The data are consistent with the
\end{abstract}

Parts of this work have been published in abstracted forms $(7,8)$.

Dr. Bourgoignie is a recipient of a U. S. Public Health Service Research Career Development Award 7 KO 4 HL 40977.

Received for publication 2 October 1973 and in revised form 21 January 1974. view that the increased activity of the natriuretic factor in the serum of chronically uremic patients is not due to failure of excretion; rather it relates either to an increased rate of production and/or a decreased rate of degradation. The data also show that the inhibitor is detectable when $F E_{\mathrm{Na}}$ is increased, but not when uremia is associated with a sodium-retaining state.

\section{INTRODUCTION}

The inhibitor of sodium transport which has been found in the serum of patients with chronic uremia has been presumed to be a component part of the control system regulating sodium excretion, and to play a role in the genesis of the progressive natriuresis per nephron that occurs in patients with advancing chronic renal disease (1)..However, the natriuretic factor could also be a nonspecific toxic substance, which is retained in the blood of uremic patients because of failure of excretion, and which bears no relation to the dictates of sodium balance. In the latter event, the rate of excretion of the factor in the urine should be no greater in uremic patients than in normal subjects, and the appearance of the inhibitor in serum and urine of uremic patients should be independent of the concurrent patterns of sodium excretion.

In the present studies, urine from chronically uremic patients and from normal subjects was examined for the presence of the natriuretic factor. In addition, assays for the presence of the factor were performed on urine and/or serum fractions from eight patients with advanced chronic renal disease and uremia who were nephrotic and edematous. 


\section{METHODS}

Assays of urine from uremic patients. Urine samples were collected quantitatively, generally for pericds of $24 \mathrm{~h}$ in glass or plastic containers maintained at $4^{\circ} \mathrm{C}$. The samples were frozen as soon as the collections were completed. Within $24-72 \mathrm{~h}$ of collection, the total volume was concentrated 10-15-fold in a stainless steel container by lyophilization (model 5012 freeze-dryer, Refrigeration for Science, Inc., Island Park, N. Y.) and stored in plastic bottles at $-80^{\circ} \mathrm{C}$ in an ultracold cabinet (model UC 105, Kelvinator Commercial Products, Inc., Manitowoc, Wis.). Then samples of the concentrate were thawed at room temperature, centrifuged at $4^{\circ} \mathrm{C}$ to discard any precipitate, and fractionated by column chromatography in a manner identical to that described previously for the fractionation of serum samples (2). In brief, $25-\mathrm{ml}$ aliquots of the concentrated urines, equivalent to 5 -h samples of original urine, were applied to individual $2.5 \times 95-\mathrm{cm}$ columns packed with Sephadex G-25 (fine grade, Pharmacia Fine Chemicals, Inc., Piscataway, N. J.). Elution was carried out at $4^{\circ} \mathrm{C}$ by gravity at a rate of $55-65 \mathrm{ml} / \mathrm{h}$ with a solution of $10 \mathrm{mM}$ ammonium acetate at $\mathrm{pH} 6.8$. The effluent solution was collected overnight in $18 \times 150$ $\mathrm{mm}$ glass tubes using an automated fraction collector (model 7000 Ultrorac, LKB Producter AB, Stockholm, Sweden). On the basis of the ultraviolet absorption at $280 \mathrm{~nm}$ (LKB Uvicord) and of the electrical conductivity (model 5300B Conductolyzer with 5312B Conductivity cell, LKB Producter AB) tracings, the effluent solution and the contents of the tubes were pooled into several different fractions. The fraction containing the principal peaks of sodium, potassium, urea, and creatinine was discarded. As in the case with the serum samples, of several fractions eluted before and after the salt peak, natriuretic activity was contained only in the fraction appearing immediately after the salt peak (3). Only this portion of the effluent solution was then routinely prepared by pooling the contents of 10 consecutive tubes $(120 \mathrm{ml}$ total $)$ starting with the tube in which the specific conductance of the eluate had returned to base-line values and lyophilizing to dryness overnight in a glass container.

The dried eluate was then carefully dissolved in $2.5 \mathrm{ml}$ of distilled water, transferred into a screw cap glass or polyethylene counting vial, and stored at $-80^{\circ} \mathrm{C}$ until the day of assay. Each milliliter of this solution was equivalent to the volume of original urine excreted in approximately $2 \mathrm{~h}$. Storage of the concentrated urine samples or of the final fraction for periods of up to several months was found to have no influence on the natriuretic activity of the material.

The standard fractions, whether obtained from uremic patients or normal subjects, typically contained less than $10 \mathrm{meq} / \mathrm{liter}$ of sodium and $1 \mathrm{meq} / \mathrm{liter}$ of potassium. Differences were not observed between fractions from uremic patients and normal subjects for ammonium, urea, and protein concentrations. The mean values were: ammonium, $24.4 \pm 3.7 \mathrm{meq} /$ liter; urea, $15.8 \pm 2.6 \mathrm{mg} / 100 \mathrm{ml}$; and protein, $2.0 \pm 0.6 \mathrm{mg} / \mathrm{ml}$.

The day of assay the sample was thawed, adjusted to a $\mathrm{pH}$ of 7.4, and to sodium and potassium concentrations of 140 and $4 \mathrm{meq} / \mathrm{liter}$, respectively. All samples were prepared in a separate laboratory and the investigator performing the bioassay had no knowledge of the nature of the sample being tested.

The assays for natriuretic activity were performed on female Sprague-Dawley rats weighing from 180 to $270 \mathrm{~g}$.
The assay rats had a reduced glomerular filtration rate (GFR) and were given $0.2 \% \mathrm{NaCl}$ to drink for 2 days before performance of an assay. The rationale for using this model relates to the observation that, although the natriuretic factor from human urine has been found to produce a natriuretic response in normal hydropenic rats, the sensitivity of salt-loaded rats with a reduced nephron population to the factor appears increased substantially (4). The details of the assay procedure have been described previously (3). In brief, between 8:00 and 9:00 a.m. the rats were anesthetized lightly with ether to permit the insertion of catheters into the urinary bladder, one femoral artery, and a jugular vein. The rats were then placed in a plastic restraining device and allowed to recover from the anesthesia. No fluid replacement for surgical losses or for urine flow during the first $30 \mathrm{~min}$ period of recovery was provided. Between 10:00 and 11:00 a.m. a priming dose of $\left[{ }^{14} \mathrm{C}\right]$ inulin (New England Nuclear, Boston, Mass.) was administered in a volume of $0.4-0.6 \mathrm{ml}$ and a. sustaining solution of radioactive inulin in isotonic saline was infused at a rate of $20 \mu \mathrm{l} / \mathrm{min}$. As in the previous study with serum fractions, if the rate of urine flow during the equilibration period exceeded the rate of the sustaining infusion by more than $25 \mu \mathrm{l} / \mathrm{min}$, a second infusion of isotonic saline was administered at a rate equal to the difference and the second infusion rate was maintained constant throughout the experiment (3). After approximately $2 \mathrm{~h}$, clearance periods were initiated for determination of absolute $\left(\mathrm{U}_{\mathrm{Na}} \mathrm{V}\right)$ and fractional $\left(\mathrm{FE}_{\mathrm{Na}}\right)$ sodium excretion ${ }^{1}$ and GFR.

At least six control clearance periods ranging from 10 to $20 \mathrm{~min}$ in duration were obtained. After the fourth period, the control phase was terminated as soon as two consecutive clearance periods were obtained in which urine flow rate varied by less than $10 \%$. The test solution consisting of either a urine fraction from a uremic patient or the comparable urine fraction from a normal subject was administered intravenously, generally between 1:00 and 2:00 p.m., in a volume of no greater than $1 \mathrm{ml}$ at a rate of $100 \mu \mathrm{l} / \mathrm{min}$. With the exception of the dose-response studies described in the text, the amount of the fraction administered was harvested from the volume of original urine excreted in $126 \pm 15 \mathrm{~min}$ for the uremic subjects and $115 \pm 10 \mathrm{~min}$ for the normal subjects. These two values do not differ significantly. At the completion of the infusion, clearance periods of $10 \mathrm{~min}$ duration were resumed and continued for $60 \mathrm{~min}$.

Arterial blood samples were collected during each clearance period for the determination of hematocrit and plasma inulin activity. Sodium and potassium concentrations were determined three times during each experiment (3). In representative experiments, arterial blood pressure of the assay animal was measured during and after infusion of the urine fraction. As in the previous experiments with the serum fractions, no change in blood pressure was detected either in the animals receiving the uremic fractions or in those receiving the normal fractions.

If evidence of intermittent obstruction to urine flow, leakage of urine around the catheter, or gross hematuria occurred, the experiment was terminated. The same criteria were employed in these studies as in the previous studies for the rejection of a completed experiment (3). These included: $(a) \mathrm{U}_{\mathrm{Na}} \mathrm{V}$ in the assay rat of less than 1 or greater than $12 \mu \mathrm{eq} / \mathrm{min}$ during the control clearance peri-

${ }^{1}$ Abbreviations used in this paper: $\mathrm{FE}_{\mathrm{Na}}$, fractional sodium excretion; $\mathrm{U}_{\mathrm{Na}} \mathrm{V}$, absolute sodium excretion. 
ods; or (b) a change in $\mathrm{U}_{\mathrm{Na}} \mathrm{V}$ of greater than $20 \%$ between the penultimate and the final control clearance period. Five experiments were discarded because of these criteria. As in our previous study with the serum fractions, in all experiments the values for $G F R, U_{\mathrm{Na}} \mathrm{V}$, and $F E_{\mathrm{Na}}$ during the last two control periods were averaged and compared with the mean of the six consecutive 10-min clearance periods obtained after infusion of the test solution (3).

The first part of the study involved the comparison of urine fractions from chronically uremic patients with those from normal subjects. Urines were obtained from 17 patients with far advanced chronic renal disease. Endogenous creatinine clearance values were less than $20 \mathrm{ml} / \mathrm{min}$ in all patients and the average was $8.7 \pm 1.4 \mathrm{ml} / \mathrm{min}$; the mean value for blood urea nitrogen (BUN) was $107 \pm 7$ $\mathrm{mg} / 100 \mathrm{ml}$; and $\mathrm{FE}_{\mathrm{Na}}$ averaged $5.7 \pm 0.8 \%$. Clinically, all of the patients, with one exception discussed below, were in external sodium balance. None of the uremic patients had congestive heart failure and none were on chronic dialysis.

For comparison, urines were obtained from 14 normal subjects (physicians and laboratory personnel). All were on an ad lib. salt intake. For several uremic patients and normal subjects, more than one study was performed using the same or different urine samples collected under the same clinical conditions.

One patient (no. 14, Table II) with a GFR of approximately $4 \mathrm{ml} / \mathrm{min}$ was studied under two very different clinical circumstances. He was admitted to the hospital after a prolonged period of anorexia, nausea, and vomiting. The first urine sample was collected when the patient was volume depleted, and had a $F E_{N a}$ of $1.2 \%$. Thereafter extracellular fluid volume was restored to normal and the patient was maintained on a 5-g salt diet. Urine was then recollected 30 days later, when $\mathrm{FE}_{\mathrm{Na}}$ was $8.3 \%$. The fractions from both urine samples were assayed.

To study the dose-response relationships, uremic or normal fractions obtained from several columns were pooled, relyophilized to dryness, and diluted in a volume of distilled water which provided either a 5- or a 10-fold increase in concentration over the standard preparation. The assays were performed by first infusing $0.1 \mathrm{ml}$ (of the 10-fold concentrate) or $0.2 \mathrm{ml}$ (of the 5 -fold concentrate). $1 \mathrm{~h}$ later, after the completion of six 10-min clearance periods, $1 \mathrm{ml}$ of the same preparation was administered and six additional periods were obtained.

Studies on nephrotic patients. These studies consisted of examination of the serum fraction from eight patients with far advanced chronic renal disease (mean GFR, 4.3 $\pm 0.6 \mathrm{ml} / \mathrm{min}$ ) who were nephrotic. All were markedly edematous, had a serum albumin of $3 \mathrm{~g} / 100 \mathrm{ml}$ or less, and were excreting greater than $5 \mathrm{~g}$ of protein/day. The urine fraction was also assayed in three of these patients. The preparation and bioassay of the serum fraction were performed in accordance with the methods and techniques previously described (3). The patients in both the nonnephrotic uremic and nephrotic uremic groups who were receiving either digitalis glycosides or a diuretic preparation are designated in Tables II and IV. 11 of the 17 nonnephrotic uremic patients and 5 of the 8 nephrotic patients received neither type of medication. As in the previous studies with the serum factor $(2,3)$, there was no correlation between the history of drug ingestion and the experimental results.

Radioactive inulin was determined in $25-50-\mu 1$ samples of either urine or plasma diluted in $10 \mathrm{ml}$ of Aquasol solution (New England Nuclear). The samples were counted
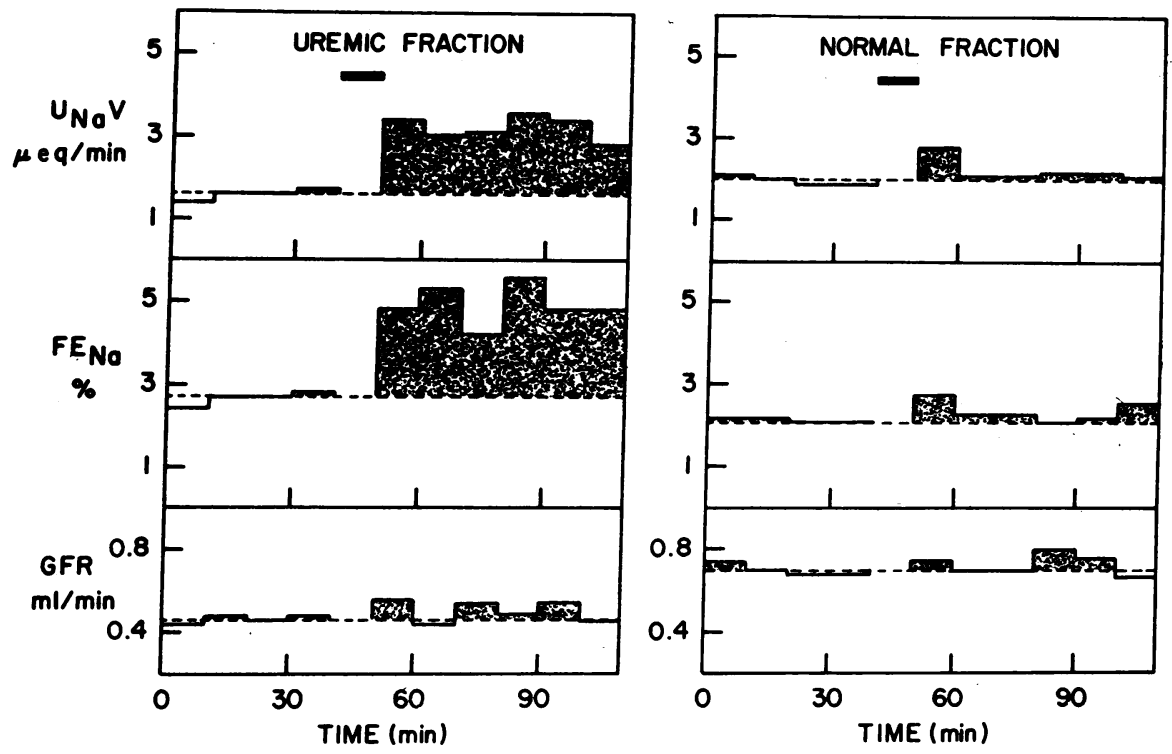

FigURE 1 Effects of uremic vs. normal urine fraction on $\mathrm{U}_{\mathrm{Na}} \mathrm{V}, \mathrm{FE}_{\mathrm{Na}}$, and GFR. The dotted line indicates the mean base-line control values observed before infusion of the fraction. In each experiment the infusion rate of fluid during the control and the experimental periods was $20 \mu \mathrm{l} / \mathrm{min}$. In the animal which received the uremic fraction, urine flow rates during the control periods averaged $31 \mu 1 / \mathrm{min}$ and increased by a mean of $12 \mu 1 / \mathrm{min}$ after infusion of the fraction. In the animal which received the normal fraction urine flow rate averaged $19 \mu \mathrm{l} / \mathrm{min}$ during the control periods and $21 \mu \mathrm{l} / \mathrm{min}$ during the experimental periods. 
TABLE I

Effects of the Urine Fraction from Normal Subjects on Glomerular Filtration Rate and Sodium Excretion

\begin{tabular}{|c|c|c|c|c|c|c|}
\hline \multirow{2}{*}{$\begin{array}{c}\text { Subject } \\
\text { no. }\end{array}$} & \multicolumn{3}{|c|}{ Control periods } & \multicolumn{3}{|c|}{ Experimental periods } \\
\hline & GFR & $\mathrm{U}_{\mathrm{Na}} \mathrm{V}$ & $\mathrm{FE}_{\mathrm{Na}}$ & $\Delta \mathrm{GFR}$ & $\Delta U_{\mathrm{NaV}}$ & $\Delta \mathrm{FE}_{\mathrm{Na}}$ \\
\hline & $m l / \min$ & $\mu e q / \min$ & $\%$ & $m l / \min$ & $\mu e q / \min$ & $\%$ \\
\hline 1 & 0.74 & 6.66 & 6.02 & +0.01 & -0.62 & -0.70 \\
\hline 2 & 0.83 & 7.91 & 7.22 & -0.12 & +1.10 & +2.40 \\
\hline 3 & 0.61 & 4.48 & 4.93 & -0.03 & -0.02 & +0.24 \\
\hline 4 & 0.78 & 6.25 & 6.53 & -0.19 & -0.70 & +0.81 \\
\hline 5 & 0.88 & 4.97 & 4.14 & +0.13 & -0.06 & -0.60 \\
\hline 6 & 0.66 & 1.79 & 2.03 & +0.05 & +0.45 & +0.34 \\
\hline 7 & 1.41 & 8.17 & 4.19 & +0.04 & -0.14 & -0.22 \\
\hline 8 & 1.07 & 2.74 & 2.24 & -0.09 & +0.70 & +0.82 \\
\hline 9 & 1.20 & 2.51 & 1.84 & +0.02 & +0.76 & +0.20 \\
\hline $10 a$ & 0.49 & 5.13 & 8.07 & -0.08 & +1.46 & +4.45 \\
\hline$b$ & 1.33 & 4.85 & 3.38 & -0.05 & +1.21 & +0.89 \\
\hline $11 a$ & 2.02 & 6.41 & 2.25 & -0.42 & -0.32 & +0.44 \\
\hline$b$ & 1.31 & 5.59 & 3.19 & +0.04 & +2.86 & +1.21 \\
\hline $12 a$ & 0.98 & 8.08 & 5.80 & +0.24 & +2.99 & +0.54 \\
\hline$b$ & 0.41 & 3.51 & 6.05 & -0.02 & +2.88 & +5.24 \\
\hline $13 a$ & 0.34 & 1.30 & 3.39 & -0.04 & -0.64 & -1.41 \\
\hline$b$ & 0.91 & 3.66 & 2.96 & -0.14 & -1.70 & -1.06 \\
\hline $14 a$ & 1.62 & 5.14 & 2.45 & -0.28 & -1.16 & -0.12 \\
\hline $\boldsymbol{b}$ & 1.21 & 2.74 & 2.24 & -0.09 & +0.70 & +0.82 \\
\hline Mean & 0.99 & 4.92 & 4.19 & -0.05 & +0.53 & +0.77 \\
\hline \pm & 0.10 & 0.47 & 0.44 & 0.03 & 0.31 & 0.39 \\
\hline
\end{tabular}

The mean values for $\mathrm{UNaV}_{\mathrm{Na}}$ and $\mathrm{FE}_{\mathrm{Na}}$ for the clearance periods obtained over the $\mathbf{6 0}$ min interval after infusion of the fractions were compared with the mean values obtained during the last two control clearance periods. The values under "experimental periods" thus represent the difference in GFR, $\mathrm{UNaV}_{\mathrm{Na}}$, and $\mathrm{FE}_{\mathrm{Na}}$ between the mean experimental and the control values.

in a Tri-Carb liquid scintillation spectrometer (model 3330, Packard Instrument Co., Inc., Downers Grove, Ill.). Sodium and potassium were measured using a flame photometer (model 143, Instrumentation Laboratory, Inc., Lexington, Mass.) and the $\mathrm{pH}$ of the fractions during their preparation for infusion was measured with a glass electrode. The variation for sets of measurements is expressed as the standard error of the mean. Statistical analysis was performed using Student's $t$ test and significance in the text is expressed as the $2 P$ value.

\section{RESULTS}

Assays of urine from nonnephrotic uremic patients. Two representative experiments are shown in Fig. 1 demonstrating the effects of the infusion of a urine fraction from a uremic patient, and from a normal subject. Values are shown for $\mathrm{U}_{\mathrm{Na}} \mathrm{V}, \mathrm{FE}_{\mathrm{Na}}$, and GFR. With the uremic fraction, $\mathrm{U}_{\mathrm{Na}} \mathrm{V}$ increased from the control level during the first postinfusion period and values remained above the control level throughout the six periods of observation. $\mathrm{FE}_{\mathrm{Na}}$ followed a similar pattern. The mean increments in $\mathrm{U}_{\mathrm{Na}} \mathrm{V}$ and $\mathrm{FE}_{\mathrm{Na}}$ were $1.53 \mu \mathrm{eq} /$ min and $2.09 \%$, respectively. GFR showed no significant change. With the administration of the urine fraction from the normal subject, an increase in $U_{\mathrm{Na}} \mathrm{V}$ and $\mathrm{FE}_{\mathrm{Na}}$ was noted during the first postinfusion period only. Thereafter values returned towards the baseline and the comparison of the mean postinfusion values with the control values showed an increase of $0.45 \mu \mathrm{eq} / \mathrm{min}$ for $\mathrm{U}_{\mathrm{Na}} \mathrm{V}$ and $0.34 \%$ for $\mathrm{FE}_{\mathrm{Na}}$.

The results of 19 assays in which the urine fractions from 14 normal subjects were tested and 28 assays in which the test solution consisted of urine fractions from 17 patients with chronic uremia are shown in Tables I and II, respectively. The change in GFR after both normal and uremic fractions was small, inconsistent in direction, and not statistically significant; nor was there a significant difference between the change in GFR between the two groups. $\mathrm{U}_{\mathrm{Na}} \mathrm{V}$ increased by a mean of 0.53

TABLE II

Effects of the Urine Fraction from Patients with Chronic Uremia on Glomerular Filtration Rate and Sodium Excretion

\begin{tabular}{|c|c|c|c|c|c|c|}
\hline \multirow{2}{*}{$\begin{array}{c}\text { Patient } \\
\text { no. }\end{array}$} & \multicolumn{3}{|c|}{ Control periods } & \multicolumn{3}{|c|}{ Experimental periods } \\
\hline & GFR & $\mathrm{UNaV}_{\mathrm{Na}}$ & $\mathrm{FE}_{\mathrm{Na}}$ & $\Delta \mathrm{GFR}$ & $\Delta \mathrm{U}_{\mathrm{Na}} \mathrm{V}$ & $\Delta \mathrm{FE}_{\mathrm{Na}}$ \\
\hline & $m l / m i n$ & $\mu e q / \min$ & $\%$ & $\mathrm{ml} / \mathrm{min}$ & $\mu e q / \min$ & $\%$ \\
\hline $1 a$ & 0.50 & 2.80 & 4.21 & +0.02 & +1.93 & +2.56 \\
\hline$b$ & 0.52 & 2.43 & 3.24 & +0.02 & +2.80 & +3.66 \\
\hline$c$ & 0.58 & 4.51 & 5.18 & +0.06 & +1.81 & +1.35 \\
\hline$d$ & 0.80 & 2.30 & 2.19 & -0.02 & +0.48 & +0.90 \\
\hline$e$ & 0.66 & 3.18 & 3.54 & +0.08 & +1.37 & +0.94 \\
\hline $2 a$ & 0.58 & 5.15 & 6.58 & +0.04 & +3.37 & +3.71 \\
\hline$b$ & 0.50 & 2.41 & 3.62 & +0.06 & +1.42 & +1.49 \\
\hline $3 a$ & 0.97 & 4.12 & 3.26 & -0.08 & +4.90 & +4.58 \\
\hline$b$ & 1.24 & 4.12 & 2.77 & +0.07 & +1.82 & +1.06 \\
\hline $4 a$ & 0.36 & 9.27 & 21.91 & $\mathbf{0}$ & +3.12 & +7.97 \\
\hline$b$ & 1.96 & 8.57 & 3.25 & -0.23 & +0.63 & +0.75 \\
\hline $5 a$ & 0.41 & 5.09 & 9.01 & -0.09 & -0.04 & +2.46 \\
\hline$b$ & 1.87 & 6.97 & 2.97 & +0.05 & +2.75 & +1.01 \\
\hline$c$ & 1.56 & 3.54 & 2.01 & -0.42 & +1.80 & +2.17 \\
\hline 6 & 0.59 & 6.81 & 8.49 & +0.09 & +2.06 & +1.31 \\
\hline 7 & 0.41 & 4.12 & 7.81 & -0.05 & +0.64 & +2.63 \\
\hline 8 & 0.78 & 4.25 & 4.23 & +0.02 & +1.28 & +1.19 \\
\hline 9 & 0.47 & 1.69 & 2.86 & +0.04 & +1.53 & +2.09 \\
\hline $10 a$ & 0.91 & 4.03 & 3.32 & -0.03 & +1.44 & +1.44 \\
\hline$b$ & 1.11 & 6.49 & 4.06 & -0.08 & +2.32 & +1.87 \\
\hline 11 & 0.45 & 1.88 & 3.07 & -0.08 & -0.03 & +1.79 \\
\hline 12 & 1.49 & 9.07 & 4.67 & -0.06 & -0.47 & -0.08 \\
\hline 13 & 1.08 & 8.59 & 5.38 & -0.04 & +0.40 & +0.40 \\
\hline $14 a^{*}$ & 1.50 & 6.57 & 3.24 & -0.16 & -1.39 & -0.40 \\
\hline$b$ & 0.47 & 2.39 & 4.32 & +0.05 & +1.54 & +1.55 \\
\hline 15 & 1.15 & 3.94 & 2.80 & -0.25 & +2.72 & +2.92 \\
\hline 16 & 0.46 & 5.30 & 8.87 & +0.01 & +0.50 & +0.77 \\
\hline 17 & 0.79 & 7.04 & 7.17 & 0 & +1.56 & +1.67 \\
\hline Mean & 0.84 & 4.82 & 5.21 & -0.03 & +1.62 & +2.01 \\
\hline$\pm \mathrm{SE}$ & 0.09 & 0.44 & 0.76 & 0.02 & 0.23 & 0.31 \\
\hline
\end{tabular}

Results are expressed as in Table I.

* Sample $14 a$ is not included in the statistical analysis (see Methods). One patient (7) was receiving $500 \mathrm{mg}$ hydrochlorothiazide daily for hypertension and five patients $(6,9,10,11$, and 13$)$ were receiving a maintenance dose of a digitalic preparation. The other 13 patients received neither medication. 
$\pm 0.31 \mu \mathrm{eq} / \mathrm{min}$ and FExa increased by a mean of $0.77 \pm$ $0.39 \%$ after administration of the normal fraction. Neither change differs significantly from zero. After administration of the uremic fraction, $U_{\mathrm{Na}} \mathrm{V}$ increased by a mean of $1.62 \pm 0.23 \mu \mathrm{eq} / \mathrm{min}$ and $\mathrm{FE}_{\mathrm{Na}}$ increased by a mean of $2.01 \pm 0.31 \%$. Both increases differ significantly from zero $(P<0.001)$. The difference between the two groups is also significant for $\mathrm{U}_{\mathrm{Na}} \mathrm{V}(P<0.01)$ and $\mathrm{FE}_{\mathrm{Na}}(P<0.02)$. If all of the results from each individual patient who was studied more than once, whether they represent replicate studies of the same urine sample or studies of different urine samples collected under similar clinical conditions are entered as a single value, the difference between the two groups remains highly significant for both $\mathrm{U}_{\mathrm{Na}} \mathrm{V}(P<0.01)$ and for $\mathrm{FE}_{\mathrm{Na}}(P<0.005)$.

Fig. 2 depicts the mean changes in $\mathrm{U}_{\mathrm{Na}} \mathrm{V}$ and $\mathrm{FE}_{\mathrm{Na}}$, expressed as a percentage of control values, after infusion of the urine fractions from normal subjects and patients with chronic uremia. With the urine fractions from the normal subjects, insignificant increases in $\mathrm{U}_{\mathrm{Na}} \mathrm{V}$ and $\mathrm{FE}_{\mathrm{Na}}(10.4 \pm 7.3$ and $13.7 \pm 7.0 \%$, respectively) were observed. After infusion of the urine fractions from the uremic patients, $\mathrm{U}_{\mathrm{Na}} \mathrm{V}$ increased by a mean of $40.5 \pm$ $6.2 \%$ and $\mathrm{FE}_{\mathrm{Na}}$ increased by a mean of $46.8 \pm 6.9 \%$. Both of these changes differ significantly from zero $(P<$ 0.001 ) and are significantly different from the changes observed after infusion of the fractions from normal subjects $\left(P<0.005\right.$ for both $U_{\mathrm{Na}} \mathrm{V}$ and $\left.\mathrm{FE}_{\mathrm{Na}}\right)$.

Fig. 3 shows mean changes in $U_{\mathrm{Na}} \mathrm{V}, F E_{\mathrm{Na}}$, and GFR for each of the six postinfusion clearance periods. The values are expressed as a percentage of the respective control values and, for each period, the response to the normal fractions is compared with that to the uremic fractions. With the normal fractions, a significant increase in $\mathrm{U}_{\mathrm{Na}} \mathrm{V}$ and $\mathrm{FE}_{\mathrm{Na}}$ was observed during the first postinfusion period only, concomitant with a small, al- beit insignificant, increase in GFR. In the succeeding periods $U_{\mathrm{Na}} \mathrm{V}$ and $F E_{\mathrm{Na}}$ did not differ significantly from the control values. In contrast, after infusion of the uremic fractions, $\mathrm{U}_{\mathrm{Na}} \mathrm{V}$ and $\mathrm{FE}_{\mathrm{Na}}$ were significantly greater than the control values in each of the six clearance periods $(P<0.001$ for all periods $)$. Moreover, with the exception of the first period for $U_{\mathrm{Na}} \mathrm{V}$, and periods 1 and 2 for $F E_{\mathrm{Na}}$, the differences between the two groups were significant. In none of the periods did the values for GFR differ significantly between the two groups.

The sequential assays on a patient studied first with extracellular fluid volume depletion and again after volume repletion are included in Table II as experiment $14 a$ and $b$. In the intial assay, both $\mathrm{U}_{\mathrm{Na}} \mathrm{V}$ and $\mathrm{FE}_{\mathrm{Na}}$ decreased slightly. In the second assay, the changes in $\mathrm{U}_{\mathrm{Na}} \mathrm{V}$ and $\mathrm{FE}_{\mathrm{Na}}$ averaged $+1.54 \mu \mathrm{eq} / \mathrm{min}$ and $+1.55 \%$, respectively.

The difference between the response to the uremic fractions and normal fractions could not be related to a difference in net fluid balance during the course of the experiments. The data referable to external fluid balance in both groups of assay rats are shown in Table III. The total infusion rates were closely comparable in the two groups. However, in the rats receiving the normal fractions, urine flow rates were essentially equal to the infusion rates whereas, in the rats receiving the uremic fractions, urine flow rates exceeded the infusion rates before and after administration of the test solution. Thus, the natriuresis occurred with the uremic fractions despite negative fluid balance in the assay rats.

Dose-response experiments using normal and uremic fractions are shown in Fig. 4. With the uremic fraction, the initial dose, equivalent to 49 min of urine, was administered in a volume of $0.1 \mathrm{ml}$. $\mathrm{U}_{\mathrm{Na}} \mathrm{V}$ during the six postinfusion clearance periods increased by a mean of $1.82 \mu \mathrm{eq} / \mathrm{min}$ over the control value. $1 \mathrm{ml}$ of the same concentrate (equivalent to the urine excreted in 490
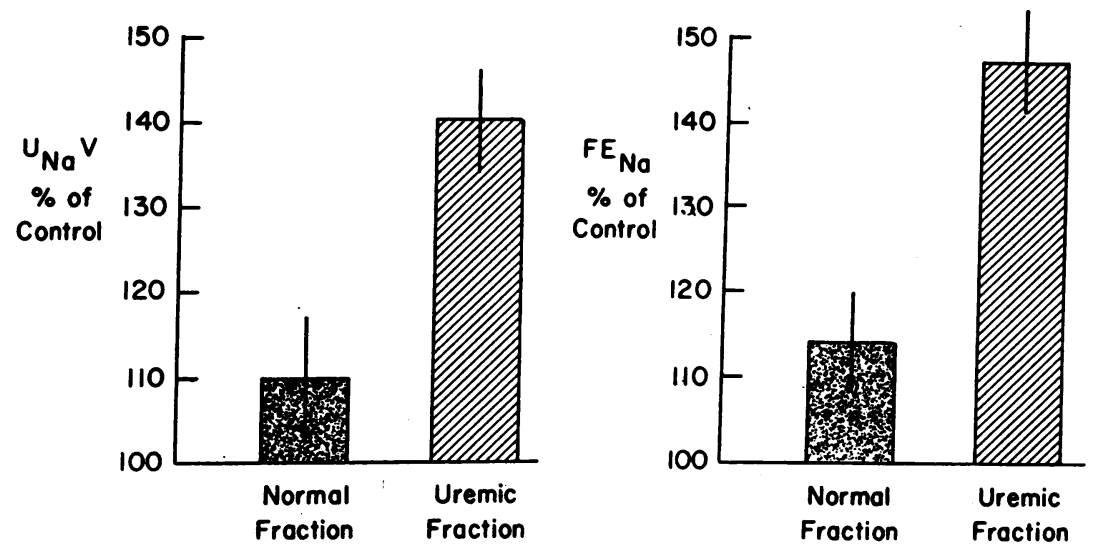

FIGURE 2 Mean changes, $\pm \mathrm{SE}$, in $\mathrm{U}_{\mathrm{Na}} \mathrm{V}$ and $\mathrm{FE}_{\mathrm{Na}}$ expressed as percent of control values, after infusion of urine fractions from normal subjects and from chronically uremic patients. 


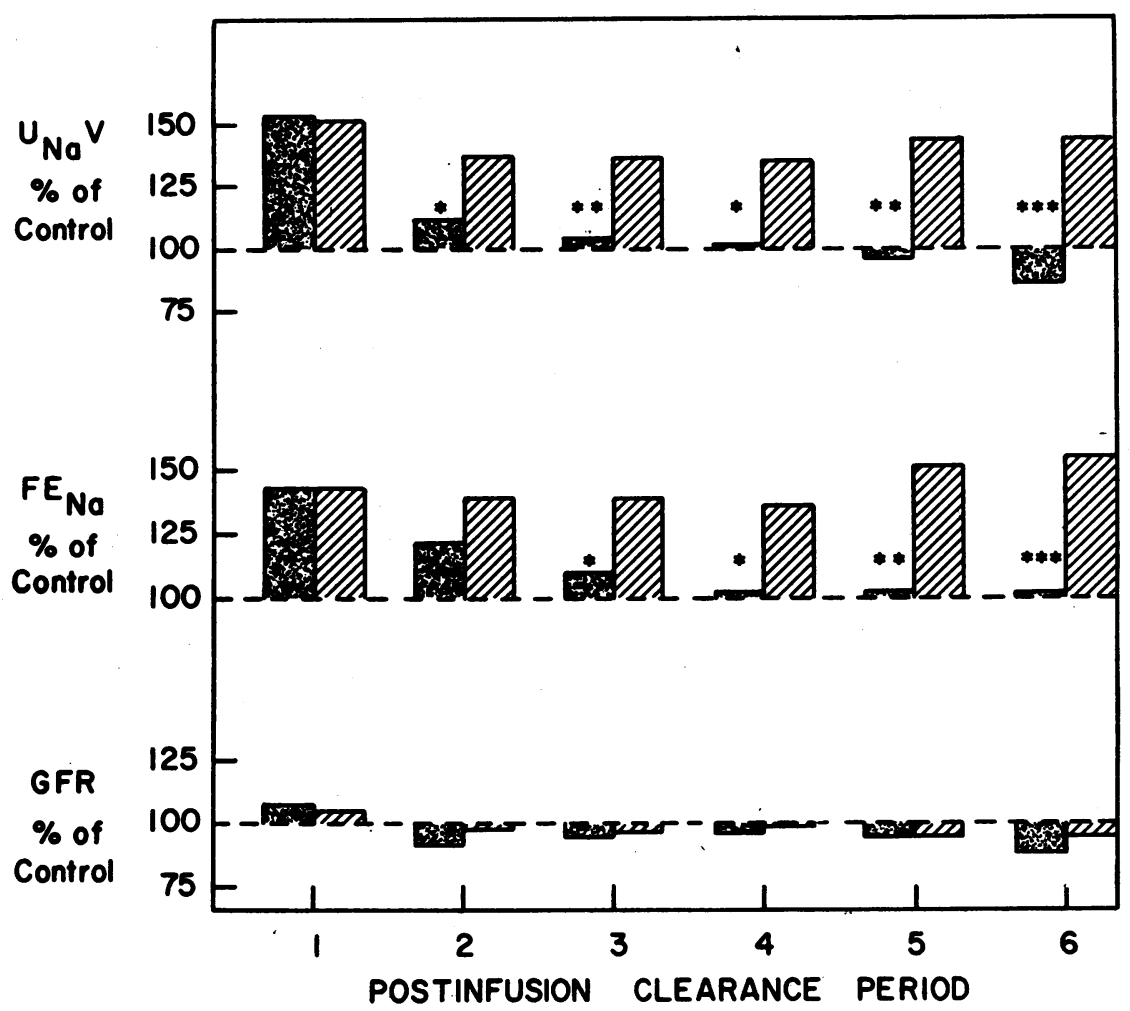

FIGURE 3 Mean changes in $\mathrm{U}_{\mathrm{Na}} \mathrm{V}, \mathrm{FE}_{\mathrm{Na}}$, and GFR, expressed as percent of control values, for each of the six clearance periods after infusion of urine fractions from normal subjects (stippled bars) and from chronically uremic patients (hatched bars). Significant differences between the responses to the normal fractions and the uremic fractions are indicated as (*) for $P<0.02,\left({ }^{* *}\right)$ for $P<0.005$, and $\left({ }^{* * *}\right)$ for $P<0.001$. Each clearance period was of 10 min duration.

min) was then administered. $\mathrm{U}_{\mathrm{Na}} \mathrm{V}$ rose to a peak of $19 \mu \mathrm{eq} / \mathrm{min}$ in the second post-infusion period. Values then fell sharply presumably because no fluid replacement was given and the rat became markedly volume depleted and sustained a substantial fall in GFR. The administration of $0.2 \mathrm{ml}$ of urine fraction from a normal subject (obtained from the urine excreted in $93 \mathrm{~min}$ ) produced no increase in $\mathrm{U}_{\mathrm{Na}} \mathrm{V}$. With the injection of $1 \mathrm{ml}$ of the same fraction (equivalent to urine excreted during 465 $\min$ ), $\mathrm{U}_{\mathrm{Na}} \mathrm{V}$ increased from a mean value of $3.6 \mu \mathrm{eq} / \mathrm{min}$ during the control periods to a peak of $7.1 \mu \mathrm{eq} / \mathrm{min}$ during the second postinfusion period.

Changes in $\mathrm{FE}_{\mathrm{Na}}$ for these experiments are also shown in Fig. 4. With the uremic fraction $F E_{N a}$ in-

TABLE III

External Fluid Balance during the Control and the Experimental Periods for the Two Groups of Assay Rats

\begin{tabular}{|c|c|c|c|c|c|}
\hline \multirow[b]{2}{*}{ Group of assay rats } & \multirow[b]{2}{*}{ Infusion rate } & \multicolumn{2}{|c|}{ Control periods } & \multicolumn{2}{|c|}{ Experimental periods } \\
\hline & & Urine flow & Balance & Urine flow & Balance \\
\hline & $\mu l / \min$ & $\mu l / \min$ & $\mu l / \min$ & $\mu l / \min$ & $\mu l / \min$ \\
\hline Normal fraction & $47.8 \pm 2.4$ & $46.0 \pm 4.1$ & $+1.8 \pm 3.2$ & $47.6 \pm 4.3$ & $0.2 \pm 4.1$ \\
\hline Uremic fraction & $50.0 \pm 2.3$ & $57.1 \pm 4.0$ & $-7.1 \pm 4.5$ & $64.7 \pm 4.1$ & $-14.7 \pm 4.0$ \\
\hline
\end{tabular}

Fluid balance represents the difference between the infusion rate and the urine flow rate.

Control and experimental periods are defined in Table I.

The values correspond to those for the same control and experimental periods presented in Tables I and II. 


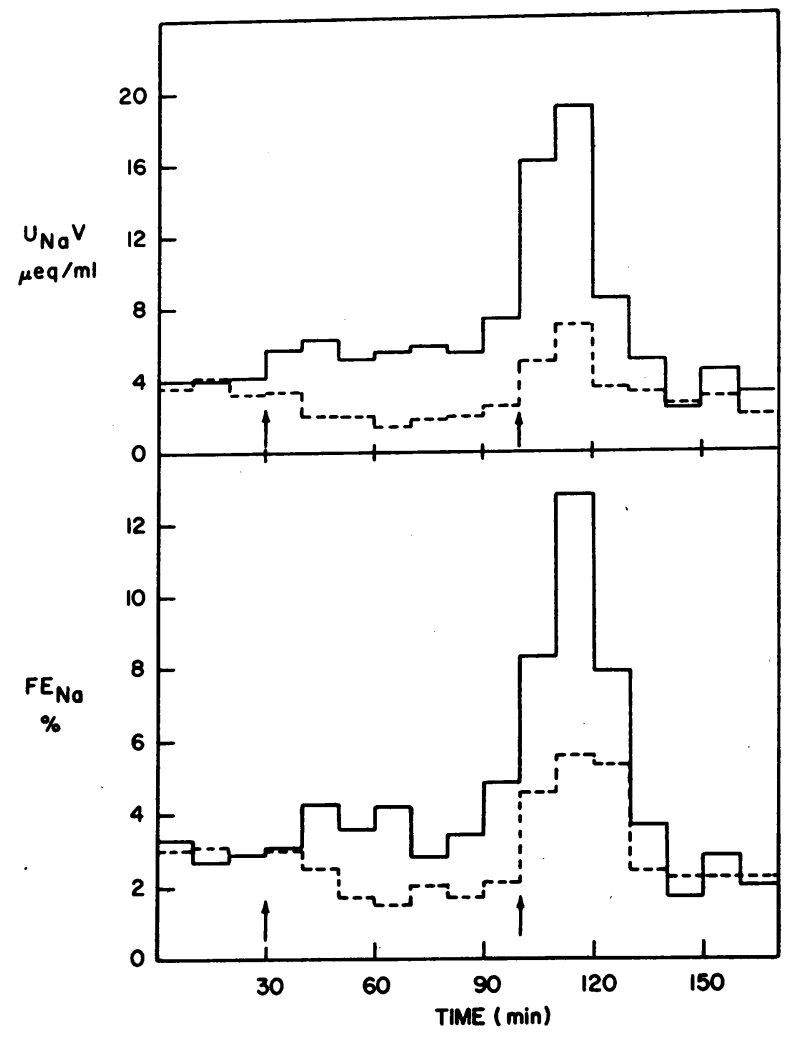

Figure 4 Dose-response experiments with urine fractions from a uremic patient (solid line) and a normal subject (broken line). Absolute values for $\mathrm{U}_{\mathrm{Na}} \mathrm{V}$ (upper panel) and $\mathrm{FE}_{\mathrm{Na}}$ (lower panel) are shown. The initial dose (first arrow) was equivalent to $43 \mathrm{~min}$ of urine for the uremic sample and $95 \mathrm{~min}$ of urine for the normal sample. At the second arrow, the doses infused were equivalent to 465 and $490 \mathrm{~min}$ of urine for the uremic and the normal sample, respectively.

creased from $2.8 \%$ to mean values of $3.8 \%$ after the first infusion and $5.2 \%$ after the second infusion. The peak value for $\mathrm{FE}_{\mathrm{Na}}$ was $12.8 \%$. With the normal fraction mean $\mathrm{FE}_{\mathrm{Na}}$ values changed from 2.9 to $1.9 \%$ and then to $3.4 \%$. The peak value for $F E_{N a}$ after the second infusion was $5.6 \%$. The mean values for $F E_{\mathrm{N} 2}$ in four dose-response experiments using uremic fractions were $2.9 \%$ (control), 3.5\% (first injection), and $4.9 \%$ (second injection).

Studies on nephrotic patients. Table IV presents the results of 12 experiments from the eight patients with the nephrotic syndrome. Serum fractions were infused in nine studies and urine fractions in three. $\mathrm{U}_{\mathrm{Na}} \mathrm{V}$ and $\mathrm{FE}_{\mathrm{Na}}$ did not increase significantly in 10 studies using the fractions from 7 of the 8 patients. The serum fraction from the eighth patient increased $\mathrm{U}_{\mathrm{Na}} \mathrm{V}$ by a mean of $1.85 \mu \mathrm{eq} / \mathrm{min}$ and $\mathrm{FE}_{\mathrm{Na}}$ by a mean of $1.94 \%$. The urine fraction from the same patient also produced an in-
TABLE IV

Effects of Serum and Urine Fractions from Patients with

Chronic Uremia and the Nephrotic Syndrome on Glomerular Filtration Rate and Sodium Excretion

\begin{tabular}{|c|c|c|c|c|c|c|}
\hline \multirow{2}{*}{$\begin{array}{c}\text { Patient } \\
\text { no. }\end{array}$} & \multicolumn{3}{|c|}{ Control periods } & \multicolumn{3}{|c|}{ Experimental periods } \\
\hline & GFR & $\mathrm{UNaV}_{\mathrm{Na}}$ & $\mathrm{FE}_{\mathrm{Na}}$ & $\Delta \mathrm{GFR}$ & $\Delta \mathrm{UNa}_{\mathrm{Na}}$ & $\Delta F E_{N a}$ \\
\hline & $m l / m i n$ & $\mu e q / \min$ & $\%$ & $m l / m i n$ & $\mu e q / \min$ & $\%$ \\
\hline 1 Serum & 0.83 & 7.54 & 6.33 & +0.13 & +0.79 & -0.54 \\
\hline 2 Serum & 0.46 & 2.25 & 3.64 & 0.00 & -0.80 & -0.80 \\
\hline 3 Serum & 0.35 & 2.97 & 6.59 & -0.03 & -1.06 & -1.99 \\
\hline 4 Serum & 0.52 & 10.19 & 14.75 & -0.10 & -6.03 & -7.29 \\
\hline 5 Serum & 0.54 & 7.70 & 10.50 & -0.03 & -0.24 & +0.23 \\
\hline $6 a$ Serum & 0.55 & 5.41 & 8.04 & +0.11 & -1.45 & -2.86 \\
\hline$b$ Serum & 0.46 & 2.63 & 4.30 & -0.02 & -0.19 & -0.10 \\
\hline Urine & 0.84 & 1.37 & 1.23 & -0.13 & +0.51 & +0.71 \\
\hline 7 Serum & 0.68 & 5.78 & 6.15 & -0.03 & -0.73 & -0.77 \\
\hline Urine & 1.29 & 7.41 & 4.35 & 0.00 & -2.17 & -1.30 \\
\hline 8 Serum & 0.68 & 6.81 & 7.92 & +0.01 & +1.85 & +1.94 \\
\hline Urine & 1.51 & 11.59 & 6.26 & -0.14 & +1.80 & +1.78 \\
\hline
\end{tabular}

Results are expressed as in Table $\mathbf{I}$.

Therapy included furosemide in one patient (4) and furosemide and digitalis in two patients ( 1 and 8 ). The other five patients received neither medication.

crease in $\mathrm{U}_{\mathrm{Na}} \mathrm{V}$ and $\mathrm{FE}_{\mathrm{Na}}$ in the assay rat. This patient was seen as an outpatient 3 wk after his urine was collected. During this interval he had undergone a spontaneous diuresis and lost $3 \mathrm{~kg}$ of body weight.

Fig. 5 depicts the average values for the mean changes in $U_{\mathrm{Na}} V$ and $F E_{\mathrm{Na}}$, previously reported (3), for the serum fractions from nonedematous chronically uremic patients in external sodium balance. The results are compared with those for the same serum fraction from the eight uremic patients with the nephrotic syndrome. The mean value for GFR in the natriuretic uremic patients

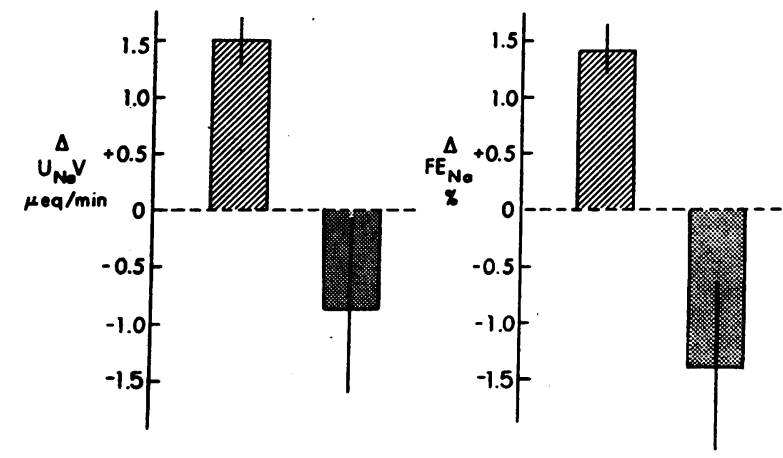

Figure 5 Mean changes, $\pm \mathrm{SE}$, in $\mathrm{U}_{\mathrm{Na}} \mathrm{V}$ and $\mathrm{FE}_{\mathrm{Na}}$ produced by serum fractions from patients with chronic uremia in the absence (hatched bars) and in the presence (dotted bars) of the nephrotic syndrome. The results of 42 assays, in which the serum fraction from nonedematous patients with chronic uremia was tested, have been previously reported (3). 
was $5.5 \mathrm{ml} / \mathrm{min}$ in comparison to the mean value for the nephrotic patients of $4.3 \mathrm{ml} / \mathrm{min}$. Values for BUN for the two groups were similar. The mean increase in $\mathrm{U}_{\mathrm{Na}} \mathrm{V}$ with serum fractions from the nonnephrotic chronically uremic patients was $1.52 \mu \mathrm{eq} / \mathrm{min}$. The mean value for the nephrotic uremic patients was $-0.87 \mu \mathrm{eq} / \mathrm{min}$. The values for $\mathrm{FE}_{\mathrm{Na}}$ for the same groups were +1.37 and $-1.35 \%$, respectively. The differences between the two groups of chronically uremic patients are highly significant, both for changes in $\mathrm{U}_{\mathrm{Na}} \mathrm{V}(P<0.001)$ and $\operatorname{FE}_{\mathrm{Na}}(P<0.001)$.

\section{DISCUSSION}

The present experiments were performed in an effort to develop additional information about the significance of the circulating inhibitor of sodium transport that has been found in the serum of patients with chronic uremia. The rationale for seeking a natriuretic factor in uremic patients relates to the fact that a progressive rise in $\mathrm{FE}_{\mathrm{Na}}$ (and sodium excretion per nephron) typically occurs in patients with chronic renal disease as GFR falls. At very low levels of $\mathrm{GFR}, \mathrm{FE}_{\mathrm{Na}}$ values may exceed $30-40 \%$ in patients who ingest only an average amount of salt (5). Thus, it was postulated, that if a natriuretic hormone contributes to the modulation of sodium excretion in health (where values for $\mathrm{FE}_{\mathrm{Na}}$ typically are less than $1 \%$ ), the activity of the hormone might be markedly increased in patients with chronic uremia (1). But the demonstration of a circulating factor with natriuretic activity does not, per se, establish either that the inhibitor is a physiologic substance or that it contributes in a regulated manner to the modulation of sodium excretion in uremia. For example, the inhibitory factor could be one of the multitude of substances retained in the blood of chronically uremic patients due to the failure of its excretion. Though it could still contribute to the natriuresis per nephron under these circumstances, this effect would be a fortuitous one.

The approximate molecular weight of the serum natriuretic factor was estimated to be between 500 and 3,000 the basis of its ultrafiltration characteristics (2). Thus, the factor could be filterable and might be excreted in the urine.

The present data document the presence of a natriuretic factor in the urine of patients with chronic uremia who were in external sodium balance on an unrestricted salt intake and who had appropriately high rates of $\mathrm{FE}_{\mathrm{Na}}$. The degree of natriuresis produced in the assay rats using the amount of fraction harvested from an average of a 2-h urine sample was equivalent to that obtained from $10 \mathrm{ml}$ of uremic serum.

In contrast, the same gel filtration fraction of urine from normal individuals failed to produce a significant increase in either $\mathrm{U}_{\mathrm{Na}} \mathrm{V}$ or $\mathrm{FE}_{\mathrm{Na}}$ in the assay rats. More- over, for both parameters of sodium excretion, the differences between normal and uremic fractions were highly significant.

Several points of evidence suggest that the inhibitor obtained in urine may be identical to that observed in serum. Both active fractions have the same elution characteristics in the gel filtration system employed, appearing after the major peaks of sodium, potassium, urea, and creatinine. Both are heat stable and resist refrigeration at $-80^{\circ} \mathrm{C}$. Both inhibit transcellular sodium transport by the urinary bladder of the toad ( 2 , 6 ), when added to the serosal surface but neither affects sodium transport when added to the mucosal surface $(2,6)$. Finally, both are inactivated by leucine amino peptidase $(7,8)$.

Thus, the elevated level of the natriuretic factor in the serum of chronically uremic patients exists in the face of excretion rates in the urine which are also increased in relation to normal subjects. This observation is inconsistent with the thesis that the material is retained in the blood due to failure of its excretion. Rather, it indicates that the natriuretic factor is produced in greater quantities in the uremic patients and/ or that its rate of inactivation is diminished.

The second major question which was addressed in these studies concerns the relationship between the patterns of sodium excretion in chronic uremia and the activity of the natriuretic factor. If the factor is unrelated to the control system for the regulation of sodium excretion, its presence in serum and its excretion in urine of chronically uremic patients should be independent of the intensity of the natriuretic state. The availability of a group of eight patients with advanced uremia who had the nephrotic syndrome and were in a sodium-retaining state provided a unique opportunity to examine this question. The mean GFR in these patients was $4.3 \mathrm{ml} / \mathrm{min}$ and the mean BUN was $136 \mathrm{mg} / 100 \mathrm{ml}$. Despite the high grade uremia, no natriuretic activity could be demonstrated in the fractions from seven of the eight patients with the nephrotic syndrome. In the one patient with positive serum and urine assays a spontaneous natriuresis of major proportion took place shortly after the urine sample was collected. $^{2}$ The observations made with the two urine fractions from the uremic patient who was studied first with a $\mathrm{FE}_{\mathrm{Na}}$ of $1.2 \%$ and again, 30 days later, with a $\mathrm{FE}_{\mathrm{Na}}$ of $8.3 \%$ lend further support to the view that there is a relationship between the activity of the natriuretic factor and the concurrent patterns of so-

\footnotetext{
${ }^{2}$ Since these studies were completed a second patient with the nephrotic syndrome and a GFR of $15 \mathrm{ml} / \mathrm{min}$ has been observed to develop a spontaneous diuresis with the loss of $10 \mathrm{~kg}$ of edema fluid. In the midst of his natriuretic state, his urine was assayed and found to be strongly positive.
} 
dium excretion. Finally, in studies by Schmidt, Bourgoignie, and Bricker (9), which will be reported separately, it was found that dogs subjected to experimental reduction of renal mass demonstrated the presence of the circulating inhibitor of sodium transport at low GFR if sodium intake was maintained constant throughout; however, if sodium intake was decreased in exact proportion to the decrement in GFR, such that $\mathrm{FE}_{\mathrm{Na}}$ remained at less than $1 \%$ throughout, no natriuretic activity could be detected.

The composite data are consistent with the view that the circulating inhibitor of sodium transport present in chronically uremic patients cannot be explained by a failure of excretion. Rather it appears to be produced in increased amounts and/or to be degraded at a decreased rate. The inhibitor also seems to appear in the serum and urine only when uremic patients exhibit an increased rate of sodium excretion per nephron and it is not detectable when uremia is associated with a sodium-retaining state.

\section{ACKNOWLEDGMENTS}

The authors are grateful to Marjorie Stolzenberg and Seung Ki Yoo for technical assistance and to Pat Kanakos and Elvira Pudano for secretarial assistance.

This investigation was supported by grants PO1-AM16281, TO1-HL05928, and 5 MO1 RR50-12 from the National Institutes of Health and by the Florence and Theodore Baumritter Kidney Center. Part of the studies on patients with the nephrotic syndrome were performed at Washington University School of Medicine, St. Louis, Mo., and that portion of the investigation was supported by grant AM-09976.

\section{REFERENCES}

1. Bricker, N. S., R. W. Schmidt, H. Weber, and J. Bourgoignie. 1973. The modulation of sodium excretion in chronic renal disease; the possible role of a natriuretic hormone. In Modern Diuretic Therapy in the Treatment of Cardiovascular and Renal Disease, London, May 1972. Excerpta Medica Foundation, Publishers, Amsterdam. 40.

2. Bourgoignie, J., S. Klahr, and N. S. Bricker. 1971. Inhibition of transepithelial sodium transport in the frog skin by a low molecular weight fraction of uremic serum. J. Clin. Invest. 50: 303. .

3. Bourgoignie, J. J., K. H. Hwang, C. Espinel, S. Klahr, and N. S. Bricker. 1972. A natriuretic factor in the serum of patients with chronic uremia. J. Clin. Invest. $51: 1514$.

4. Fine, L. G., H. Weber, J. J. Bourgoignie, and N. S. Bricker. 1973. On the end-organ responsiveness of the rat kidney to the natriuretic factor from urine of patients with chronic uremia. Abstracts from the American Society of Nephrology. $6: 35$.

5. Slatopolsky, E. K., O. Elkan, C. Weerts, and N. S. Bricker. 1968. Studies on the characteristics of the control system governing sodium excretion in uremic man. J. Clin. Invest. $47: 521$.

6. Kaplan, M. A., J. J. Bourgoignie, J. Rosecan, and N. S. Bricker. 1974. The effects of the natriuretic factor from uremic urine on sodium transport, water and electrolyte content, and pyruvate oxidation by the isolated toad bladder. J. Clin. Invest. 53 : 1568.

7. Bourgoignie, J., R. W. Schmidt, K. Hwang, T. Nawar, S. Klahr, L. Chase, and N. S. Bricker. 1972. On the nature of the circulating natriuretic factor in chronic uremia. J. Clin. Invest. 51: 12a. (Abstr.)

8. Ipakchi, E., J. Bourgoignie, K. Hwang, and N. S. Bricker. 1973. On the apparent increase in production of natriuretic factor in chronic uremia J. Clin. Invest. $52: 42 a$. (Abstr.)

9. Schmidt, R. W., J. J. Bourgoignie, and N. S. Bricker. 1974. On the adaptation in sodium excretion in chronic uremia. The effects of proportional reduction of sodium intake. J. Clin. Invest. 53: 1736. 